\title{
Temporal and spatial variability of phytoplankton and mixotrophs in a temperate estuary
}

Nicole C. Millette

Virginia Institute of Marine Science

Marcella da Costa

Jordan W. Mora

Rebecca J. Gast

Follow this and additional works at: https://scholarworks.wm.edu/vimsarticles

Part of the Marine Biology Commons

\section{Recommended Citation}

Millette, Nicole C.; da Costa, Marcella; Mora, Jordan W.; and Gast, Rebecca J., Temporal and spatial variability of phytoplankton and mixotrophs in a temperate estuary (2021). Marine Ecology Progress Series, 677, 17-31.

doi: $10.3354 /$ meps 13850

This Article is brought to you for free and open access by the Virginia Institute of Marine Science at W\&M ScholarWorks. It has been accepted for inclusion in VIMS Articles by an authorized administrator of W\&M ScholarWorks. For more information, please contact scholarworks@wm.edu. 


\title{
Temporal and spatial variability of phytoplankton and mixotrophs in a temperate estuary
}

\author{
Nicole C. Millette ${ }^{1,2, *}$, Marcella da Costa ${ }^{2,3}$, Jordan W. Mora $^{4}$, Rebecca J. Gast ${ }^{1}$ \\ ${ }^{1}$ Department of Biology, Woods Hole Oceanographic Institution, 86 Water St, Woods Hole, MA 02543, USA \\ ${ }^{2}$ Virginia Institute of Marine Science, William \& Mary, Gloucester Point, VA 23062, USA \\ ${ }^{3}$ Department of Biology, Saint Augustine's University, 1315 Oakwood Ave, Raleigh, NC 27610, USA \\ ${ }^{4}$ Waquoit Bay National Estuarine Research Reserve, 131 Waquoit Hwy, Waquoit, MA 02536, USA
}

\begin{abstract}
A significant proportion of phototrophic species are known to be mixotrophs: cells that obtain nutrients through a combination of photosynthesis and prey ingestion. Current methods to estimate mixotroph abundance in situ are known to be limited in their ability to help identify conditions that favor mixotrophs over strict autotrophs. For the first time, we combine microscopic analysis of phototrophic taxa with immunoprecipitated bromodeoxyuridine (BrdU)labeled DNA amplicon sequencing to identify and quantify active and putative mixotrophs at 2 locations in a microtidal temperate estuary. We analyze these data to examine spatial and temporal variability of phytoplankton and mixotrophs. Microscopy-based phototrophic diversity and abundances reveal expected seasonal patterns for our 2 stations, with the start of growth in winter and highest abundances in summer. Diatoms tend to dominate at the site with less stratification, while dinoflagellates and euglenids are usually more prominent at the stratified station. The BrdU-based mixotroph identifications are translated to the microscopy identification and abundances to estimate the proportion of mixotrophs (cells $>10 \mu \mathrm{m}$ in size) at both sites. The average proportion of potential mixotrophs is higher at the station with higher stratification $(51 \%)$ compared to the station with lower stratification $(30 \%)$, and potential mixotrophs tend to be higher in summer, although we did not conduct BrdU experiments in any of the other seasons. Combining the identification of active mixotrophs through the uptake of BrdU-labeled bacteria with robust abundance measurements can expand our understanding of mixotrophs across systems.
\end{abstract}

KEY WORDS: Phytoplankton $\cdot$ Mixotrophs $\cdot$ Estuaries $\cdot$ Chl $a$

\section{INTRODUCTION}

Phototrophic plankton form the base of most aquatic food webs, producing organic carbon that will be utilized by higher trophic levels. Phototrophic biomass is commonly estimated by measuring $\mathrm{chl} a$ concentrations in water samples because the chl $a$ pigment is present in almost all phototrophs and has been shown to be a direct proxy for their biomass (Steele 1962, Strickland 1965, Cullen 1982), albeit an imperfect one (Buchanan 2020). As a result of the emphasis on the collection of chl a concentration data, the potential importance of mixotrophs in per-

${ }^{*}$ Corresponding author: nmillette@vims.edu forming some combination of both photosynthesis and ingestion goes largely unknown (Millette et al. 2018). It is necessary to understand the nutritional modes being used by the phototrophic assemblage because these factors contribute to variability in biogeochemical cycling (Lomas et al. 2014, Brierley 2017), water quality (Shashi Shekhar et al. 2008, Valiela et al. 2016), and productivity and stability (Ptacnik et al. 2008, Vallina et al. 2014, Tian et al. 2017). For example, recent modeling studies that examined the potential contribution of mixotrophy to carbon cycling propose that mixotrophs could substantially increase the amount of primary production

() The authors 2021. Open Access under Creative Commons by Attribution Licence. Use, distribution and reproduction are unrestricted. Authors and original publication must be credited. 
and the transfer of carbon to higher trophic levels (Mitra et al. 2016, Ward \& Follows 2016).

A major impediment to incorporating mixotrophy into environmental studies is the inability to reasonably estimate the abundance of mixotrophs in a system. Fluorescently labeled bacteria and fluorescent microspheres have long been used to estimate mixotroph abundance and ingestion rates, but research shows that these methods underestimate true abundance (Anderson et al. 2017, Li et al. 2021). More recently, a few studies have identified potential mixotrophs in field samples via taxonomy, referring to phototrophs that have been found to consume prey in previous experiments (Haraguchi et al. 2018, Leles et al. 2019, Cesar-Ribeiro et al. 2020, Schneider et al. 2020). For example, Schneider et al. (2020) used microscopy-based taxonomic information from a long-term North Sea dataset to link the occurrence and abundance of potential mixotrophs with abiotic conditions (offshore versus estuarine). While this method of potential mixotroph identification provides the opportunity to reanalyze available microscopy samples and estimate the proportion of mixotrophs, it likely overestimates their abundance since species presence does not necessarily translate to mixotroph behavior.

Here, we apply a relatively new molecular method to constrain the identification of mixotrophs in microscopy data to known active mixotrophs in the same environment. By feeding live bacteria labeled with bromodeoxyuridine (BrdU) to a plankton sample, it is possible to ascertain cells that ingest the bacteria and incorporate the BrdU into their DNA through an immunoprecipitation process (Fay et al. 2013). From there, the immunoprecipitated samples are amplified and sequenced to identify the mixotrophs taxonomically as amplicon sequence variants (ASVs) that are associated with protists known to contain chloroplasts (Gast et al. 2018). Mixotrophs identified from the BrdU experiments can then be matched with taxa identified in microscopy samples to estimate the abundance and proportion of mixotrophs greater than $10 \mu \mathrm{m}$ in size. The BrdU method improves upon previous research by curating a list of active mixotrophs specific to our study site. Improved estimation of the abundance and proportion of mixotrophs can advance our understanding of how mixotrophs vary in response to local environmental conditions.

The goal of this study is to investigate the spatial and temporal variability of the phytoplankton (strict phototrophs) and mixotrophs present in a temperate estuary (Waquoit Bay, MA, USA) and identify possible environmental conditions driving their variabil- ity. Due to intensive long-term monitoring, there is good temporal and spatial coverage on chl a concentration and other environmental data in Waquoit Bay, but data on the phototrophic taxa present are extremely limited. This research project has 3 specific objectives: (1) identify the phototrophic taxa present in Waquoit Bay, (2) determine which of these taxa are capable of phagotrophy, and (3) examine what environmental factors are associated with the spatial and temporal variability in phyto- and mixotrophic abundance and proportion.

Data were collected on the abundance of phototrophic taxa and environmental conditions over a 15 mo period (2018-2019) at 2 of the long-term monitoring locations in the Waquoit Bay Estuary. Laboratory experiments were conducted over a 3 mo period in the summer of 2019 to determine which phototrophic taxa were capable of ingesting bacteria. This study provides some of the first data on the proportion of potential mixotrophs within the phototrophic assemblage throughout the year in a temperate estuary.

\section{MATERIALS AND METHODS}

\subsection{Waquoit Bay}

The Waquoit Bay Estuary (Fig. 1) is a shallow microtidal system that is part of the National Estuarine Research Reserve System (NERRS). At its deepest, the estuary is approximately $3 \mathrm{~m}$ deep at low tide, but on average the estuary is only $1.5 \mathrm{~m}$ deep at mean low tide. The average tidal range for the estuary is roughly $1 \mathrm{~m}$. Salinity ranges from 27 to 32 at the mouth of the estuary, while the tidally influenced tributaries experience a much greater salinity amplitude of 5 to 30 .

Each reserve within the NERRS is required to maintain at least 4 System-Wide Monitoring Program (SWMP) stations where a series of water quality data are collected (Centralized Data Management OfficeNERRS SWMP manual https://cdmo.baruch.sc.edu/ request-manuals/). In addition to the SWMP, the Waquoit Bay National Estuarine Research Reserve (WBNERR) coordinates a citizen science water quality monitoring program, the Waquoit BayWatchers (WBW). The WBW program involves 12 to 16 volunteers who monitor 10 locations throughout the Waquoit Bay Estuary. At each site, the volunteers measure standard water quality parameters and collect water samples which are analyzed for a suite of nutrient components and chl a concentration. 


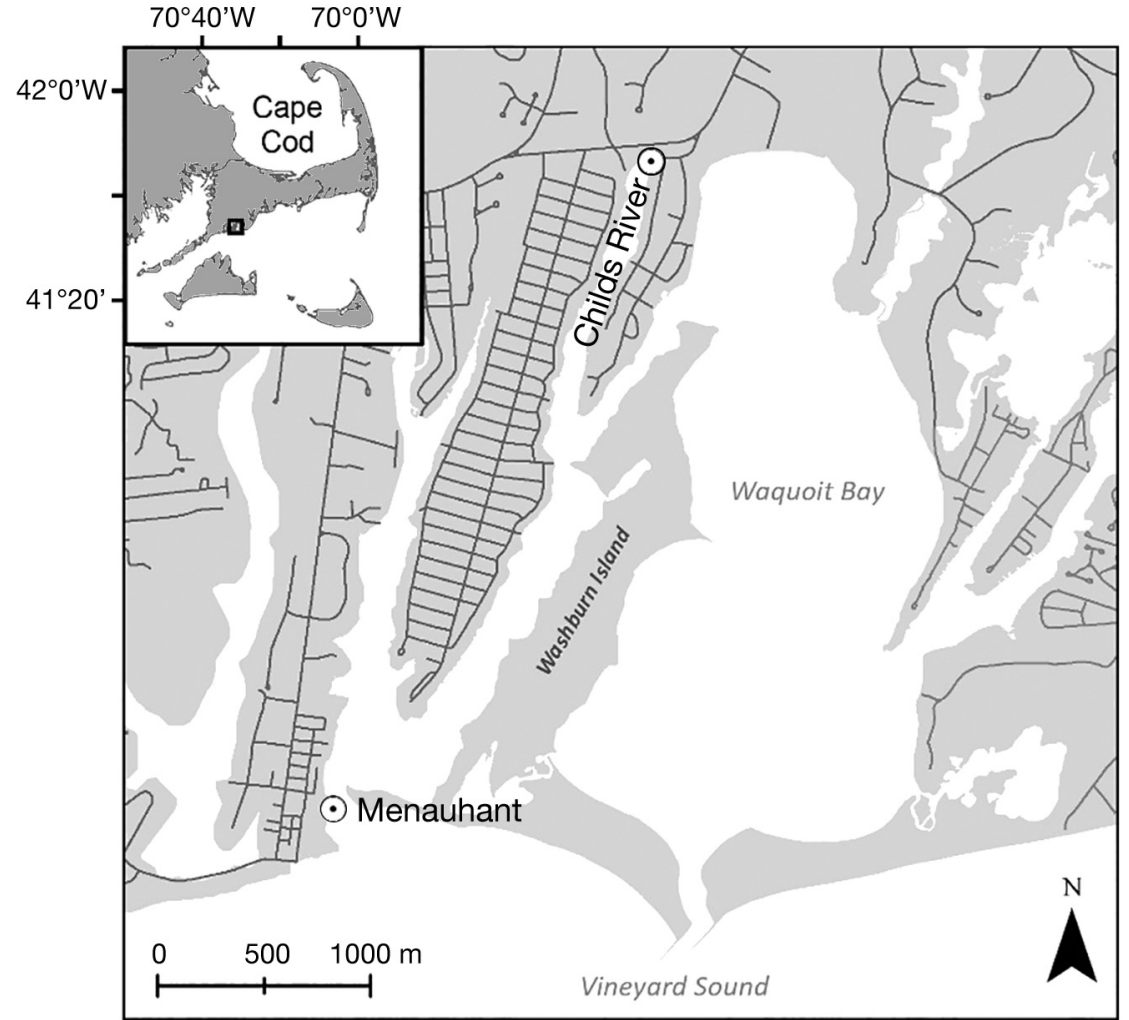

Fig. 1. Location of Childs River and Menauhant stations in Waquoit Bay, Cape Cod, MA, USA

The WBNERR monitoring stations at Childs River (CR) and Menauhant (MH) were sampled between May 2018 and August 2019 in coordination with the WBW program (Fig. 1). These 2 dockside stations were sampled every $2 \mathrm{wk}$ in June through September and sampled once a month from October through May, for a total of 23 collection dates. These stations were selected because of the regular sample frequency and the difference in chl a concentration; CR experiences relatively high chl a concentrations during the summer months, while MH generally has low chl a concentrations overall (Howes et al. 2013).

The $\mathrm{MH}$ site has an average depth of approximately $2 \mathrm{~m}$ at low tide and is located at one of the estuary's southern inlets where the marine water mass from Vineyard Sound exchanges with the estuarine outflow. The average water depth at CR is approximately $1 \mathrm{~m}$ at low tide, and the site receives freshwater flow from surface water and groundwater discharge upstream while also experiencing mesohaline tidal influence from Vineyard Sound (TomaskyHolmes et al. 2013). Due to dense residential developments within the sub-watershed, excess nitrogen from leaching septic systems has resulted in an overabundance of macroalgae, excess phytoplankton production, and thus frequent summer hypoxia events at the CR site (Valiela et al. 1992, D'Avanzo \& Kremer 1994, Foster \& Fulweiler 2019).

\subsection{Environmental data}

At each station, the WBW volunteers used a YSI Pro2030 sonde to collect water temperature $\left({ }^{\circ} \mathrm{C}\right)$, salinity, and dissolved oxygen concentrations $\left(\mathrm{mg} \mathrm{l}^{-1}\right)$ at the surface $(0.25 \mathrm{~m}$ below water surface) and bottom (within 2-5 $\mathrm{cm}$ of benthic sediments) of the water column. Sampling and measurements occurred before 09:00 $\mathrm{h}$ on an outgoing tide, usually within $3 \mathrm{~h}$ of slack low tide. For the nutrient and chl a analysis, the volunteers collected 21 of water in 2 pre-rinsed 11 acid-washed amber Nalgene bottles with a custom-designed pole sampler. The water samples were filtered onto GF/Fs within $2 \mathrm{~h}$ of sampling and frozen at $-20{ }^{\circ} \mathrm{C}$ until analyzed for nutrient $(\mu \mathrm{M})$ and $\mathrm{chl} \mathrm{a}\left(\mu \mathrm{g} \mathrm{l}^{-1}\right)$ concentrations at the Center for Coastal Studies Water Quality Laboratory in Provincetown, MA, following a protocol developed by WBNERR based on standard operating procedures outlined by the EPA (US EPA 2006).

Using the surface and bottom values for water temperature and salinity, a stratification index was calculated according to Eq. (4) in Cohen (1985). The index is between 0 and 1 , with 0 being the highest stratification and 1 being no stratification.

\subsection{Microscopy}

In tandem with the volunteers, additional water samples were collected using a 51 Niskin bottle (General Oceanic) from just below the surface for microscopy analysis of phototrophic taxa at both stations. Triplicate $500 \mathrm{ml}$ water samples were immediately preserved with $5 \%$ Lugol's solution in glass amber bottles and sealed with electrical tape. Each $500 \mathrm{ml}$ Lugol's sample was concentrated in the laboratory by settling for $24 \mathrm{~h}$ in a $1 \mathrm{l}$ container and then gently pipetting liquid off the top to reduce the total volume. Periodically, this liquid was checked to confirm that organisms were not being removed from 
the concentrated sample. The final concentrated volume for samples ranged from 9 to $85 \mathrm{ml}$. Samples collected at CR for 6 sampling dates (13 and 27 Jul 2018, 10 and 25 Aug 2018, and 2 and 16 Aug 2019) were not concentrated because cell abundances were very high. To identify taxa to the lowest classification level and estimate abundances (cells $\mathrm{ml}^{-1}$ ), samples were analyzed with a Zeiss Axiovert S 100 microscope at 400× magnification on a Sedgewick rafter slide (Sherr \& Sherr 1993). This magnification allowed us to count all microplankton and larger nanoplankton species ( 10-200 $\mu \mathrm{m}$ length), but cells that were too small to be identified were excluded from the counts. A minimum of 300 cells were counted per sample. The focus was on phototrophic taxa, but a single heterotrophic dinoflagellate (Protoperidinium sp.) was included in the counts and analysis.

\subsection{BrdU-labeled bacterial ingestion experiments}

From June 2019 to August 2019, BrdU incorporation experiments were conducted using water collected via Niskin bottles at both sites. BrdU, a thymidine nucleotide analog, is incorporated into prey genomic DNA. When labeled prey are eaten, BrdU is transferred to the grazer genomic DNA via digestion, assimilation, and replication. This material is then recovered by immunoprecipitation and followed by eukaryotic ribosomal amplicon sequencing.

Seawater was taken back to the laboratory and prefiltered through $100 \mu \mathrm{m}$ Nitex mesh, and triplicate incubations were set up for + BrdU and - BrdU bacterial additions (see Text S1 in the Supplement at www.int-res.com/articles/suppl/m677p017_supp.pdf for details on labeling bacteria with BrdU). The $100 \mu \mathrm{m}$ seawater $(250 \mathrm{ml})$ was placed into a $500 \mathrm{ml}$ Whirl-Pak bag, and bacteria were added to a final concentration of $10^{5}$ to $10^{6}$ cells ml ${ }^{-1}$. Bags were incubated for $48 \mathrm{~h}$ at $15^{\circ} \mathrm{C}$ with a $14 \mathrm{~h}$ light: $10 \mathrm{~h}$ dark cycle. From each incubation bag, $100 \mathrm{ml}$ was collected onto $47 \mathrm{~mm}, 3 \mu \mathrm{m}$ Isopore filters, which reduced the amount of bacterial material in the final sample. DNA was isolated following the hot detergent method reported by Gast et al. (2004) using $400 \mu \mathrm{l}$ of lysis buffer.

\subsection{Immunoprecipitation of + BrdU DNA and sequence analysis}

DNA from +BrdU incubations was immunoprecipitated using an anti-BrdU monoclonal antibody fol- lowing the process reported by Fay et al. (2013) and Gast et al. (2018), with modifications (see Text S1 for details). Amplicons for sequencing were generated from -BrdU DNA and +BrdU immunoprecipitated DNA by PCR amplification of the V4 region of the $18 \mathrm{~S}$ ribosomal gene using primers 574V4F (5'-[TCG TCG GCA GCG TCA GAT GTG TAT AAG AGA CAG]CGG TAA YTC CAG CTC YV-3') and 1132V4R (5'-[GTC TCG TGG GCT CGG AGA TGT GTA TAA GAG ACA G]CCG TCA ATT HCT TYA ART-3'), described in Hugerth et al. (2014) and modified to include $5^{\prime}$ adapter sequences (in square brackets) for Illumina MiSeq. Each sample was amplified in triplicate using up to $3 \mu$ l template DNA, 1.25 units AmpliTaq Gold 360 DNA polymerase, $2 \mathrm{mM} \mathrm{MgCl}_{2}, 2 \mu \mathrm{l} 2.5 \mu \mathrm{M}$ dNTPs, and $2.5 \mu \mathrm{l} 10 \times$ reaction buffer ( $25 \mu$ l total volume). Amplification conditions were $95^{\circ} \mathrm{C}$ for $8 \mathrm{~min} ; 40$ cycles of $95^{\circ} \mathrm{C}$ for $30 \mathrm{~s}$, $58^{\circ} \mathrm{C}$ for $30 \mathrm{~s}, 72^{\circ} \mathrm{C}$ for $90 \mathrm{~s} ; 72^{\circ} \mathrm{C}$ for $5 \mathrm{~min} ; 4^{\circ} \mathrm{C}$ hold. Replicate reactions were pooled and purified using Qiagen Min-Elute. Purified amplicons were sent to the University of Rhode Island Genomics and Sequencing Center for library preparation and Illumina MiSeq sequencing (300 bp paired end; 600 cycle kit V2).

Only forward reads were analyzed because the fragment was too large (580 bp) to permit efficient assembly with the reverse reads. QIIME2 was used to demultiplex, denoise, remove chimeras, and quality control the forward read Illumina data (see Text S1 for details). The size of the quality-controlled forward read fragment was $200 \mathrm{bp}$ and covered the $5^{\prime}$ half of the V4 fragment routinely used for amplicon diversity (Stoeck et al. 2010, Tragin et al. 2018). Although these fragments were short, the sequence quality was high and contained useful information for taxonomic identification. ASVs were grouped at $100 \%$ identity and taxonomy assigned using the Silva 132 database. ASVs identified as bacteria, metazoa, fungi, and macroalgae were removed from the dataset, as were those that occurred only once (singletons). Raw sequence reads have been deposited at the NCBI Sequence Read Archive (PRJNA690935).

For each experiment, taxa were identified as putative bacterivores based on comparison of tag sequences between + BrdU and - BrdU samples. ASV abundances were converted to a percentage of the total tags for each sample, and the average of each -BrdU ASV was subtracted from the average of the corresponding +BrdU ASV. The ASV was considered a putative bacterivore if the subtracted value was positive and $>0.1 \%$ of the total average amplicon 
abundance and if it was present in at least 2 of the + BrdU samples. If only 1 of the +BrdU samples had the ASV, its abundance needed to be $>1 \%$ of the total average amplicon abundance to be considered. Putative bacterivores identified as taxa containing chloroplasts were then considered as putative mixotrophs. This approach was based on prior work (Fay et al. 2013), and the use of 0.1 and $1 \%$ as cutoffs was to represent the more abundant amplicons in the datasets. This balanced the effect of variability between incubation replicates and reduced the influence of non-specific recovery of extremely abundant DNA (e.g. from diatom taxa). The putative mixotroph ASV taxonomic identifications were compared to the microscopy taxa, and the qualitative identification of a microscopy taxon as a potential mixotroph was made if there were matches at the genus level.

\subsection{Analysis}

ANOSIM (Primer v7; Clarke \& Gorley 2015) was applied to the microscopy data to examine whether the data groupings based on factors of site, season, and month were significantly different. Microscopy cell counts were $\log (x+1)$ transformed to balance the contributions of dominant and rare variants. BrayCurtis resemblance matrices were generated. Oneway unordered ANOSIM was run with 999 permutations for each factor.

We utilized the +BrdU ASV taxonomic information to identify mixotroph taxa in the microscopy samples and their corresponding abundances in 2 ways. First, for only the 2019 summer microscopy samples collected in tandem with water for +BrdU experiments, taxa detected by each + BrdU experiment were identified in the corresponding microscopy samples. These are referred to as active mixotrophs because only the taxa that were identified to be grazing when the sample was collected were considered. Second, we applied any taxa detected across all +BrdU experiments to all the microscopy samples. Mixotrophic abundance estimations using the second approach are referred to as potential mixotrophs because although data on whether these taxa were consuming bacteria when the samples were collected were not available, they have demonstrated the ability to consume bacteria in other Waquoit Bay samples. Due to the limitation of microscopy (greater than $\sim 10 \mu \mathrm{m}$ ), estimates of mixotroph abundance were restricted to larger cells.

Poisson generalized linear models (GLMs) with an offset analysis were applied to examine potential environmental drivers of different taxonomic group abundances at each station using microscopy data. The environmental data (independent variables) we considered were water temperature, salinity, turbidity, ammonium, nitrate + nitrite $\left(\mathrm{NO}_{\mathrm{x}}\right)$, silicate, ortho-phosphate, dissolved inorganic nitrogen (DIN) and total nitrogen (TN) concentration, DIN: dissolved inorganic ortho-phosphate (DIP) ratio, and stratification index (0-1). The offset term was the proportion of the microscope slide that was counted for each sample. The independent variables for each model run were tested for collinearity using the car package in $\mathrm{R}$ with the variance inflation factor (VIF) function (Fox \& Weisberg 2016). The VIF function tests for variation-inflation in the GLM analysis. Any environmental variable that had a collinearity VIF value of 3 or greater (Zuur et al. 2010) was removed so that analyses were run only with variables that had $<3$ VIF. Any variables with $\mathrm{p}$-values greater than 0.05 were also removed until the selected GLM for each taxonomic group at a station had only significant variables with no collinearity. All GLM runs were conducted in R (version 3.6.3) using the built-in linear regression (glm) function.

\section{RESULTS}

\subsection{Environmental data}

Most of the environmental data collected by the WBW from May 2018 to August 2019 were significantly different between $\mathrm{MH}$ and CR (Table 1). Average salinity, dissolved bottom $\mathrm{O}_{2}$ concentrations, and stratification index were significantly higher (meaning lower stratification) at $\mathrm{MH}$ (Table 1). Average chl $a$, ammonium, $\mathrm{NO}_{\mathrm{x}}$, silicate, TN concentrations, and DIN:DIP ratio were significantly higher at CR (Table 1). Average temperature, turbidity, and phosphate concentrations were not significantly different between $\mathrm{MH}$ and CR (Table 1).

\subsection{Microscopy data}

The average $( \pm \mathrm{SE})$ phototroph abundance at $\mathrm{MH}$ was $1189 \pm 221$ cells ml $^{-1}$ compared to $7128 \pm 2070$ cells $\mathrm{ml}^{-1}$ at CR (Fig. 2). Typically, the highest abundances at CR occurred in July and August in both years, with noticeable peaks in October and December 2018 (Fig. 2). At MH, cellular abundances were highest in summer 2018, declined into fall, and then 
Table 1. Average $( \pm$ SE) water quality data collected 23 times between May 2018 and August 2019 at 2 stations in Waquoit Bay. Temp: temperature; Dissolved $\mathrm{O}_{2}$ : bottom dissolved oxygen concentration; $\mathrm{NTU}$ : turbidity; $\mathrm{NH}_{4}^{+}$: ammonium concentration; $\mathrm{NO}_{\mathrm{x}}$ : nitrate + nitrite concentration; $\mathrm{SiO}_{2}$ : silicate concentration; $\mathrm{PO}_{4}{ }^{3-}$ : phosphate concentration; TN: total nitrogen; DIN:DIP: $\left(\mathrm{NH}_{4}{ }^{+}+\mathrm{NO}_{\mathrm{x}}\right) / \mathrm{PO}_{4}{ }^{3-}$ ratio; $\mathrm{S}$ : stratification index. ${ }^{*}$ Significant difference between the 2 stations (paired, 2 -tailed $t$-test, $\mathrm{p}<0.05$ )

\begin{tabular}{|c|c|c|c|c|c|c|c|c|c|c|c|c|}
\hline & $\begin{array}{l}\text { Temp } \\
\left({ }^{\circ} \mathrm{C}\right)\end{array}$ & Salinity & $\begin{array}{c}\text { Dissolved } \\
\mathrm{O}_{2}\left(\mathrm{mg} \mathrm{l}^{-1}\right)\end{array}$ & NTU & $\begin{array}{c}\text { Chl a } \\
\left(\mu g l^{-1}\right)\end{array}$ & $\begin{array}{l}\mathrm{NH}_{4}^{+} \\
(\mu \mathrm{M})\end{array}$ & $\begin{array}{l}\mathrm{NO}_{\mathrm{x}} \\
(\mu \mathrm{M})\end{array}$ & $\begin{array}{l}\mathrm{SiO}_{2} \\
(\mu \mathrm{M})\end{array}$ & $\begin{array}{l}\mathrm{PO}_{4}{ }^{3-} \\
(\mu \mathrm{M})\end{array}$ & $\begin{array}{c}\mathrm{TN} \\
(\mu \mathrm{M})\end{array}$ & DIN:DIP & S \\
\hline $\mathrm{CR}$ & $17.8 \pm 1.6$ & $17.1 \pm 1.6$ & $5.4 \pm 0.8$ & $2.4 \pm 0.5$ & $26.8 \pm 7.1$ & $2.7 \pm 0.4$ & $22.0 \pm 0.4$ & $44.3 \pm 4.4$ & $0.42 \pm 0.04$ & $66.6 \pm 5.8$ & $114.9 \pm 48.0$ & $0.7 \pm 0.1$ \\
\hline $\mathrm{MH}$ & $17.4 \pm 1.7$ & $30.0 \pm 0.2^{*}$ & $7.1 \pm 0.4^{*}$ & $1.7 \pm 0.5$ & $3.4 \pm 0.4^{*}$ & $1.2 \pm 0.2^{*}$ & $0.5 \pm 0.1^{*}$ & $5.1 \pm 0.8^{*}$ & $0.40 \pm 0.05$ & $24.7 \pm 1.6^{*}$ & $7.8 \pm 1.5^{*}$ & $1.0 \pm 0.0^{*}$ \\
\hline
\end{tabular}

started to increase again in winter 2019 (Fig. 2). For both stations, summer abundances were higher in 2018 compared to 2019 (Fig. 2). Forty taxa were identified over the course of $15 \mathrm{mo}$; all 40 occurred at $\mathrm{MH}$, and 37 occurred at CR (Table 2). Twenty-five diatoms, 12 dinoflagellates, 1 cryptophyte, 1 chlorophyte, and 1 euglenid were identified (Table 2). Of the taxa listed in Table 2, all contain chloroplasts except for Protoperidinium. Given the higher total cellular concentration at $\mathrm{CR}$, individual taxon abundance was normalized to total abundance to make comparisons between the 2 stations (Table 2).

Based on the ANOSIM analysis, there was a significant difference in the phototrophic assemblage between $\mathrm{MH}$ and $\mathrm{CR}$ (Table 3). The proportion of diatoms was significantly higher at $\mathrm{MH}$, and the proportions of dinoflagellates and euglenids were significantly higher at $\mathrm{CR}$, while the cryptophyte genus, Teleaulax, was consistently prominent at both stations (Table 2, Fig. 3). The phototrophic assemblage was also significantly different between seasons and months (Table 3). At CR, there was a strong seasonal variability in the proportion of different taxonomic groups, with cryptophytes and euglenids more prominent in the summer and diatoms dominating in winter and spring (Fig. 3a). There were exceptions to this pattern, with a dinoflagellate bloom in December 2018 and diatoms dominating in late July and early August 2019 (Fig. 3a). At MH, diatoms were consistently more dominant throughout the year, with an occasional increase in cryptophytes (Fig. 3b). The overall proportion of dinoflagellates was higher at $\mathrm{CR}$ than at $\mathrm{MH}$, but their proportions remained relatively consistent throughout the year at each station (Fig. 3).

At $\mathrm{CR}$, the 3 most dominant taxa were Teleaulax sp., Leptocylindrus spp., and Eutreptiella gymnastica (Table 2). At $\mathrm{MH}$, the 3 most dominant taxa were Leptocylindrus spp., Teleaulax sp., and Skeletonema spp. (Table 2). Nine diatom taxa composed a significantly higher proportion of the phototrophic assemblage at $\mathrm{MH}$ compared to $\mathrm{CR}$, while 4 dinoflagellate and 1 diatom taxa composed a significantly higher proportion of the phototrophic assemblage at CR (Table 2). At CR, the abundances of diatoms, dinoflagellates, and cryptophytes were negatively related to some form of inorganic nitrogen, and all but cryptophytes were positively related to phosphate (Table 4). At $\mathrm{MH}$, the abundances of all taxonomic groups were negatively related to phosphate and positively related to temperature (Table 5). Diatoms were positively related to the stratification index (less stratified), while dinoflagellates and cryptophytes were negatively related to the index (Table 5).

\subsection{Mixotrophy data}

Between $\mathrm{CR}$ and $\mathrm{MH}, 53$ unique ASVs identified as containing plastids were associated with BrdUlabeled bacterial ingestion over 6 sampling dates (Table 6). More than half of the mixotroph ASVs were shared at both sites, but 9 occurred only at CR and 18 at MH (Table 6). Almost half of the taxa identified as mixotrophs by this process were dinoflagellates, but other common taxa included Microglena uva-maris and Ostreococcus spp. Seven of the ASVs could be matched with 6 genera identified in microscopy samples that were collected simultaneously: Teleaulax sp. (Teleaulax uncultured eukaryote), Gyrodinium sp. (Gyrodinium uncultured eukaryote), Gymnodinium sp. (Gymnodinium sp. GSSW10), Heterocapsa spp. (H. niei and Heterocapsa uncultured dinoflagellate), Alexandrium sp. (Alexandrium uncultured eukaryote), and Scrippsiella sp. (Scrippsiella uncultured eukaryote) (Table 6). The BrdU method could be biased towards the detection of mixotrophic dinoflagellates relative to other mixotrophic taxa due to their high ribosomal gene copy number, but it was possible to detect chlorophyte, cryptophyte, and ochrophyte ASVs, and some were as abundant as the most prevalent dinoflagellate ASVs (e.g. Ostreococcus at $>1 \%$ ). Only a few of the dinoflagellate ASVs occurred at more than $1 \%$ in the mixotrophic predictions for each sample. Finally, 98 heterotrophic taxa ASVs were identified by the method (Table S1), and 


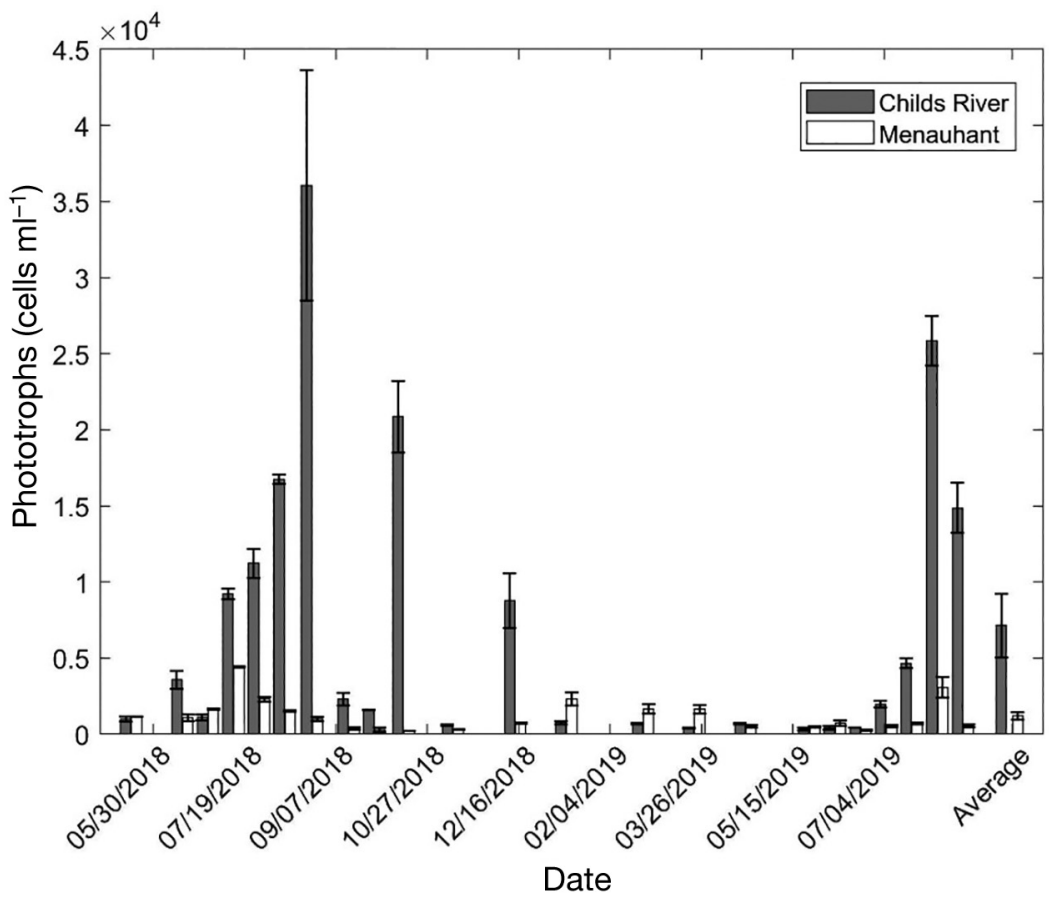

Fig. 2. Total abundance of phototrophs $(+\mathrm{SE})$ at Childs River and Menauhant between May 2018 and August 2019. Average data point is the average cellular abundance (+SE) over the course of the study. Dates are mo/d/yr

ber of cells counted (Fig. 4b). At $\mathrm{MH}$, there was an average of $149 \pm 33$ active mixotrophs $\mathrm{ml}^{-1}$ (Fig. 4a), which accounted for $26 \%$ of the average proportion of total cells counted (Fig. 4b).

Potential mixotrophs are taxa associated with the ASVs from all BrdU experiments, regardless of whether BrdU experiments were conducted on the sampling date; this was applied to all samples (Fig. 5). There was a seasonal pattern to potential mixotroph abundance, with mixotrophs generally more prevalent in the summer than in the fall, winter, or spring (Fig. 5). Mixotrophs were more abundant at CR, with an average of $4072 \pm$ 1693 potential mixotrophs $\mathrm{ml}^{-1}$ (Fig. 5a), which accounted for $51 \%$ of the average proportion of total cells counted (Fig. 5). At $\mathrm{MH}$, there was an average of $301 \pm 110$ potential mixotrophs $\mathrm{ml}^{-1}$ (Fig. 5a), which accounted for $30 \%$ of the average pro-

some were much more abundant than the dinoflagellates (e.g. a jakobid ASV at $>8 \%$ and a cercozoan ASV at $>3 \%$ ). While there may be bias associated with the response of individual organisms to the incubation conditions, this approach allowed the identification of many actively grazing taxa.

Forty-six ASVs that were identified from the BrdU experiments were not associated with taxa from the microscopy samples. These consisted of organisms that were too small to be accurately identified via microscopy (e.g. Ostreococcus spp., Micromonas sp., M. uva-maris), organisms whose identification was too generalized (e.g. Suessiaceae uncultured, Dinophyceae uncultured, Eustigmatales uncultured), or organisms that were not identified in microscopic samples, despite being large enough (e.g. Gonyanulx spinifera, Pelagodinium sp., Paragymnodinium sp.).

We used ASVs from the BrdU experiments to estimate the abundance and proportion of active mixotrophs and potential mixotrophs in the microscopy samples. Active mixotrophs are taxa that were identified to be grazing on bacteria for a specific sample date (Table 6) and then associated with microscopy samples at the sample location and date; this could only be applied to samples collected between June and August 2019 (Fig. 4). At CR, there was an average of $1623 \pm 146$ active mixotrophs $\mathrm{ml}^{-1}$ (Fig. 4a), which accounted for $34 \%$ of the average total num- portion of total cells counted (Fig. 5b). Based on the GLM analysis, the abundance of potential mixotrophs at CR was positively related to turbidity, stratification index, and phosphate concentration and negatively related to $\mathrm{NO}_{\mathrm{x}}$ and ammonium concentrations (Table 4). At $\mathrm{MH}$, potential mixotroph abundance was positively related to temperature and salinity and negatively related to stratification index, $\mathrm{NO}_{\mathrm{x}}$, and phosphate concentrations (Table 5). The proportion of potential mixotrophs (to total phototroph cells counted) at CR was positively related to temperature, stratification index, and silicate concentrations and negatively related to turbidity and $\mathrm{NO}_{\mathrm{x}}$, ammonium, and phosphate concentrations (Table 4). At $\mathrm{MH}$, the proportion of potential mixotrophs (to total phototroph cells counted) was positively related to temperature, stratification index, and $\mathrm{NO}_{\mathrm{x}}$ and ammonium concentrations and negatively related to phosphate concentrations (Table 5).

The 2 major taxonomic groups that represented the potential mixotrophs were cryptophytes and dinoflagellates, and the proportion of each group varied throughout the year and between stations (Fig. 6). On average, cryptophytes accounted for a higher proportion of the potential mixotroph abundance at both stations compared to dinoflagellates: $64.9 \pm$ $5.6 \%$ at $\mathrm{CR}$ and $79.8 \pm 0.8 \%$ and $\mathrm{MH}$. However, dinoflagellates accounted for a higher proportion of 
Table 2. Average $( \pm \mathrm{SE})$ proportion of each group or taxa at Childs River (CR) and Menauhant (MH). (-) Genera or species that were never recorded for a site. ${ }^{*}$ Significant difference between the 2 stations (paired, 2-tailed $t$-test, $\mathrm{p}<$ 0.05). Bold indicates taxa associated with amplicon sequence variants identified to ingest bacteria in the bromodeoxyuridine experiments

\begin{tabular}{|c|c|c|c|}
\hline Group & Taxon & $\mathrm{CR}$ & $\mathrm{MH}$ \\
\hline \multirow[t]{26}{*}{ Diatoms } & Asterionellopsis sp.* & $0.28 \pm 0.15$ & $3.47 \pm 1.49$ \\
\hline & Chaetoceros spp.* & $5.38 \pm 2.98$ & $9.27 \pm 2.78$ \\
\hline & Corethron sp. & - & $0.06 \pm 0.03$ \\
\hline & Coscinodiscus sp. ${ }^{*}$ & $0.05 \pm 0.02$ & $0.25 \pm 0.07$ \\
\hline & Cylindrotheca sp.* & $0.07 \pm 0.03$ & $0.20 \pm 0.07$ \\
\hline & Dactyliosolen sp. ${ }^{*}$ & $0.26 \pm 0.19$ & $1.25 \pm 0.49$ \\
\hline & Ditylum brightwellii & $0.00 \pm 0.00$ & $0.03 \pm 0.02$ \\
\hline & Entomoneis sp. & $0.01 \pm 0.01$ & $0.05 \pm 0.03$ \\
\hline & Eucampia sp. & $0.04 \pm 0.03$ & $0.12 \pm 0.07$ \\
\hline & Fragilaria sp. & $0.09 \pm 0.04$ & $0.09 \pm 0.04$ \\
\hline & Gryosigma sp. ${ }^{*}$ & $0.02 \pm 0.02$ & $0.11 \pm 0.04$ \\
\hline & Leptocylindrus spp.* & $12.50 \pm 4.76$ & $27.08 \pm 4.95$ \\
\hline & Licmophora sp. & $0.04 \pm 0.03$ & $0.62 \pm 0.35$ \\
\hline & Lithodesmium sp. & - & $0.18 \pm 0.12$ \\
\hline & Melosira sp. & $0.68 \pm 0.31$ & $0.06 \pm 0.03$ \\
\hline & Navicula spp. & $0.09 \pm 0.04$ & $0.18 \pm 0.05$ \\
\hline & Nitzschia spp.* & $2.64 \pm 1.22$ & $8.08 \pm 2.59$ \\
\hline & Odontella sp. & - & $0.09 \pm 0.08$ \\
\hline & Paralia sp. & $0.00 \pm 0.00$ & $0.03 \pm 0.02$ \\
\hline & Probosciasp. & $0.12 \pm 0.06$ & $1.40 \pm 0.71$ \\
\hline & Pseudo-nitzschia spp. & $0.54 \pm 0.20$ & $0.70 \pm 0.17$ \\
\hline & Skeletonema spp.* & $4.31 \pm 2.06$ & $8.76 \pm 2.67$ \\
\hline & Striatella sp. & $0.01 \pm 0.01$ & $0.02 \pm 0.01$ \\
\hline & Thalassionema spp.* & $0.02 \pm 0.02$ & $0.15 \pm 0.06$ \\
\hline & Thalassiosira spp. & $1.15 \pm 0.93$ & $1.70 \pm 0.94$ \\
\hline & Total diatoms* & $29.74 \pm 6.29$ & $65.05 \pm 4.39$ \\
\hline \multirow[t]{13}{*}{ Dinoflagellates } & Akashiwo sanguinea & $0.33 \pm 0.15$ & $0.11 \pm 0.07$ \\
\hline & Alexandrium sp. & $0.06 \pm 0.03$ & $0.01 \pm 0.01$ \\
\hline & Cochlodinium sp. & $0.04 \pm 0.04$ & $0.01 \pm 0.01$ \\
\hline & Dinophysis sp.* & $0.42 \pm 0.27$ & $0.01 \pm 0.01$ \\
\hline & Gymnodinium sp. & $3.71 \pm 1.69$ & $0.97 \pm 0.15$ \\
\hline & Gyrodinium sp.* & $1.76 \pm 0.48$ & $0.65 \pm 0.16$ \\
\hline & Heterocapsa rotundata & $6.41 \pm 3.90$ & $1.48 \pm 0.61$ \\
\hline & Heterocapsa triquetra* & $3.22 \pm 1.48$ & $0.38 \pm 0.19$ \\
\hline & Karlodinium sp. ${ }^{*}$ & $0.16 \pm 0.05$ & $0.04 \pm 0.02$ \\
\hline & Prorocentrum spp. & $1.82 \pm 0.61$ & $1.33 \pm 0.43$ \\
\hline & Protoperidinium sp. & $0.50 \pm 0.19$ & $0.29 \pm 0.11$ \\
\hline & Scrippsiella sp.** & $1.91 \pm 0.48$ & $0.56 \pm 0.13$ \\
\hline & Total dinoflagellates ${ }^{*}$ & $22.63 \pm 4.19$ & $6.06 \pm 0.81$ \\
\hline Cryptophytes & Teleaulax sp. & $37.25 \pm 5.82$ & $27.20 \pm 4.19$ \\
\hline Chlorophytes & Tetraselmis sp. & $0.10 \pm 0.08$ & $0.16 \pm 0.10$ \\
\hline Euglenids & Eutreptiella gymnastica* & $9.88 \pm 3.95$ & $1.53 \pm 0.47$ \\
\hline
\end{tabular}

Table 3. ANOSIM p-values (Primer v7; Clarke \& Gorley 2015) of microscopy data to examine whether the factors of site, season, and month were significant for differences between the phytoplankton communities. MH: Menauhant; CR: Childs River; n/a: not applicable

\begin{tabular}{|lcll|}
\hline & Site & Season & Month \\
\hline Microscopy both sites & 0.001 & 0.0002 & 0.0001 \\
Microscopy MH & n/a & 0.001 & 0.0008 \\
Microscopy CR & n/a & 0.0003 & 0.0001 \\
\hline
\end{tabular}

the potential mixotroph abundance at $\mathrm{CR}(35.1 \pm 5.6 \%)$ compared to $\mathrm{MH}(20.2$ $\pm 3.6 \%$ ). In general, cryptophytes were more dominant in the summer, while dinoflagellates were more dominant during winter and spring at both stations (Fig. 6).

\section{DISCUSSION}

The microscopy analysis of water samples revealed how the phototrophic assemblage differed between CR and $\mathrm{MH}$. The proportion of diatoms was significantly higher at $\mathrm{MH}$ than at $\mathrm{CR}$, while the proportions of dinoflagellates and euglenids were significantly higher at $\mathrm{CR}$ than at $\mathrm{MH}$ (Table 2). The average composition of the phototrophic assemblage at each station was potentially explained by the stability of the water column and nitrogen concentration. Diatoms are known to be better competitors in environments with a more active water column (MH), while dinoflagellates are better competitors in a more stable or stratified water column (CR; Margalef 1978, Smayda \& Reynolds 2001). Additionally, regions with better water quality, specifically low nutrient concentrations and higher irradiance levels as seen at $\mathrm{MH}$, generally support phototrophic assemblages dominated by diatoms. Conversely, regions with higher nutrients and lower irradiance levels, like those seen at CR, tend to have photosynthetic assemblages dominated by dinoflagellates (Buchanan 2020).

The seasonal and temporal variability in the phototrophic assemblage at CR generally followed the pattern expected in a temperate estuary, with diatoms more prominent in spring and flagellates more prominent in summer (Marshall et al. 2005). At $\mathrm{MH}$, diatoms tended to dominate throughout the year, but there were periods when cryptophytes would increase in proportion. Overall, abundances of diatoms, dinoflagellates, and cryptophytes at both stations were positively related to temperature, reflecting that total phototroph abundance was typically higher in warmer months. The factors related to variability in dinoflagellate 

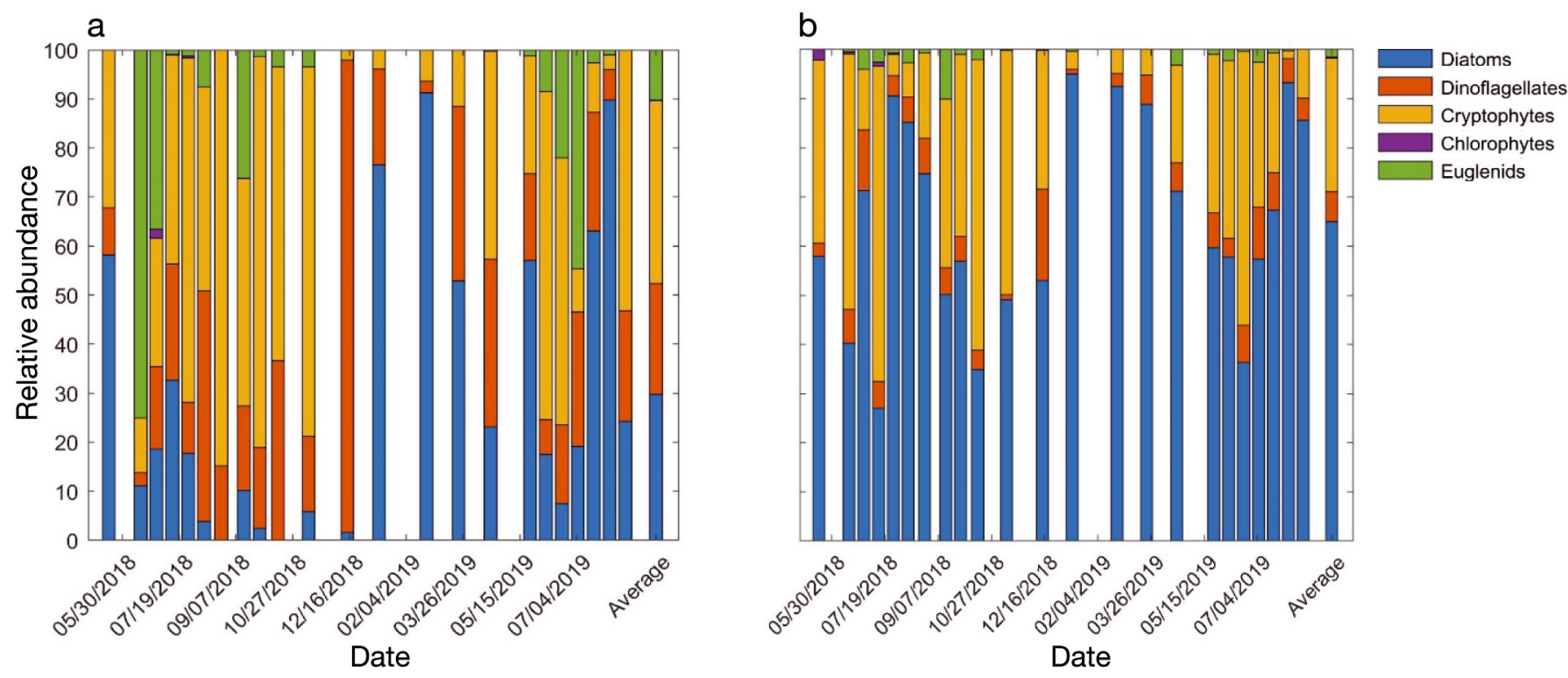

Fig. 3. Proportion of total abundance that 5 plankton groups, identified through microscopy, accounted for at each sample date (mo/d/yr) between May 2018 and August 2019 at (a) Childs River and (b) Menauhant. Average data point is the average proportion of each group over the course of the study

Table 4. Results for the Poisson generalized linear model (GLM) with an offset analysis for select groups at Childs River (CR). The factors temperature (Temp), turbidity (NTU), stratification $(\mathrm{S})$, nitrate + nitrite $\left(\mathrm{NO}_{\mathrm{x}}\right)$, ammonium $\left(\mathrm{NH}_{4}^{+}\right)$, phosphate $\left(\mathrm{PO}_{4}{ }^{3-}\right)$, and silicate $\left(\mathrm{SiO}_{2}\right)$ were used in at least 1 of the models. The residual degrees of freedom for all GLMs was 63. (-/+): factor was positively $(+)$ or negatively $(-)$ related to the dependent variable. Blank space: factor was not significantly $(\mathrm{p}>0.05)$ related to variability in the dependent variable or was removed due to collinearity (VIF $>3$ )

\begin{tabular}{lcccccccc}
\hline CR & Temp & $\mathrm{NTU}$ & $\mathrm{S}$ & $\mathrm{NO}_{\mathrm{x}}$ & $\mathrm{NH}_{4}{ }^{+}$ & $\mathrm{PO}_{4}{ }^{3-}$ & $\mathrm{SiO}_{2}$ \\
\hline $\begin{array}{l}\text { Total cryptophytes } \\
\quad \text { Teleaulax sp.) }\end{array}$ & + & - & + & - & & - & \\
Total diatoms & + & & - & - & & + & + \\
Total dinoflagellates & & + & + & & - & + & + \\
$\begin{array}{l}\text { Potential mixotroph } \\
\text { abundance }\end{array}$ & & + & + & - & - & + & \\
$\begin{array}{l}\text { Proportion of potential } \\
\text { mixotrophs }\end{array}$ & + & - & + & - & - & - & + \\
& & & & & & & & \\
\hline
\end{tabular}

Table 5. Same as Table 4 but for Menauhant (MH)

\begin{tabular}{|lcccccccc}
\hline MH & Temp & NTU & Salinity & $\mathrm{S}$ & $\mathrm{NO}_{\mathrm{x}}$ & $\mathrm{NH}_{4}{ }^{+}$ & $\mathrm{PO}_{4}{ }^{3-}$ \\
\hline $\begin{array}{l}\text { Total cryptophytes } \\
\text { (Teleaulax sp.) }\end{array}$ & + & - & + & - & & - & \\
Total diatoms & & & & & & & & \\
Total dinoflagellates & + & + & - & - & + & - & - \\
Potential mixotroph & + & & + & - & - & & - \\
abundance & & & & & & & - \\
$\begin{array}{l}\text { Proportion of potential } \\
\text { mixotrophs }\end{array}$ & + & & & + & + & + & - \\
\hline
\end{tabular}

abundance at both stations were what would be expected for a group that was more prominent in the summer: high temperature, low inorganic nitrogen (ammonium), and high stratification (negative relationship with the stratification index) (Smayda \& Reynolds 2001, Li et al. 2010, Jauzein et al. 2017). However, dinoflagellates at CR had a positive relationship with the stratification index, which implies that their abundances were higher when stratification was lower; this was unexpected. The relationship with low ammonium concentration may be the result of dinoflagellates having taken up this form of inorganic nitrogen (Halbach et al. 2019). From our analysis at $\mathrm{MH}$, the factors influencing diatom abundance differed from cryptophytes and dinoflagellates in 2 key ways: lower stratification (positively related to stratification index) and $\mathrm{NO}_{\mathrm{x}}$ concentration. Diatoms prefer low stratification and $\mathrm{NO}_{\mathrm{x}}$, so these relationships were expected, again assuming they were taking up $\mathrm{NO}_{\mathrm{x}}$ (Glibert et al. 2016). At $C R$, diatom abundance was again related to low $\mathrm{NO}_{\mathrm{x}}$ concentration but not to stratification. Overall, the stratification results for CR did 
Table 6. Amplicon sequence variants (ASVs) identified as active mixotrophs for each experiment at Childs River (CR) and Menauhant (MH) between June 2019 and August 2019 (dates as mo/d/yr). ASVs that occurred only at MH are marked with ${ }^{*}$, and those that occurred only at CR are marked with . Bold refers to ASVs associated with chloroplast-containing taxa in the microscopy samples

\begin{tabular}{|c|c|c|c|c|c|c|c|c|c|c|c|c|}
\hline \multirow[t]{2}{*}{ Plankton group / ASV } & \multicolumn{6}{|c|}{$\mathrm{CR}$} & \multicolumn{6}{|c|}{$-\mathrm{MH}$} \\
\hline & 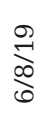 & 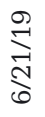 & 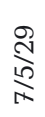 & 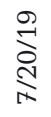 & 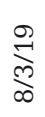 & $\frac{\infty}{\infty}$ & 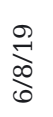 & 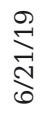 & $\underset{N}{\stackrel{\sigma}{N}}$ & 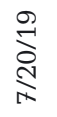 & 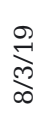 & $\stackrel{\infty}{\infty}_{\infty}^{\frac{9}{2}}$ \\
\hline \multicolumn{13}{|l|}{ Chlorophyta } \\
\hline Ostreococcus marine metagenome & $\mathrm{x}$ & $\mathrm{x}$ & & $\mathrm{x}$ & $\mathrm{x}$ & $\mathrm{x}$ & & $\mathrm{x}$ & $\mathrm{x}$ & $\mathrm{x}$ & $\mathrm{x}$ & \\
\hline Ostreococcus uncultured eukaryote ${ }^{*}$ & & & & & & & & & $\mathrm{x}$ & & $\mathrm{x}$ & \\
\hline Ostreococcus uncultured Chlorophyte & & & $\mathrm{x}$ & & & & & & & & & \\
\hline Micromonas uncultured marine eukaryote* & & & & & & & & & & & $\mathrm{x}$ & \\
\hline Tetraselmis uncultured marine eukaryote* & & & & & & & $\mathrm{x}$ & & & & & \\
\hline Tetraselmis prasinophyte sp. Xmm38S5* & & & & & & & & $\mathrm{x}$ & & & & \\
\hline Microglena uva-maris & $\mathrm{x}$ & & & $\mathrm{x}$ & $\mathrm{x}$ & & $\mathrm{x}$ & & $\mathrm{x}$ & $\mathrm{x}$ & $\mathrm{x}$ & $\mathrm{x}$ \\
\hline Chlamydomonas sp. NIES-3904* & & & & & & & & & & & $\mathrm{x}$ & \\
\hline Chlorophyceae uncultured eukaryote & & & & & $\mathrm{x}$ & & & & & & $\mathrm{x}$ & $\mathrm{x}$ \\
\hline \multicolumn{13}{|l|}{ Cryptophyceae } \\
\hline Teleaulax uncultured eukaryote & $\mathrm{x}$ & $\mathrm{x}$ & & $\mathrm{x}$ & & $\mathrm{x}$ & $\mathrm{x}$ & $\mathrm{x}$ & $\mathrm{x}$ & $\mathrm{x}$ & $\mathrm{x}$ & \\
\hline Hemiselmis uncultured phytoplankton & $\mathrm{x}$ & & $\mathrm{x}$ & $\mathrm{x}$ & & & & $\mathrm{x}$ & & $\mathrm{x}$ & & $\mathrm{x}$ \\
\hline Leucocryptos uncultured katablepharid & & & & $\mathrm{x}$ & & & & & & & $\mathrm{x}$ & \\
\hline Cryptomonadales uncultured cryptophyte* & & & & & & & & $\mathrm{x}$ & $\mathrm{x}$ & & & \\
\hline \multicolumn{13}{|l|}{ Dinoflagellata } \\
\hline Gyrodinium uncultured eukaryote & & & & $\mathrm{x}$ & & & $\mathrm{x}$ & & & & $\mathrm{x}$ & \\
\hline Paragymnodinium uncultured eukaryote ${ }^{*}$ & & & & & & & $\mathrm{x}$ & & & & & \\
\hline Polykrikos kofoidii & & $\mathrm{x}$ & $\mathrm{x}$ & $\mathrm{x}$ & & & & $\mathrm{x}$ & $\mathrm{x}$ & & $\mathrm{x}$ & \\
\hline Erythropsidinium uncultured marine dinoflagellate & & & & $\mathrm{x}$ & $\mathrm{x}$ & & & & $\mathrm{x}$ & $\mathrm{x}$ & $\mathrm{x}$ & \\
\hline Erythropsidinium agileq & & & & & & $\mathrm{x}$ & & & & & & \\
\hline Chytriodinium uncultured dinoflagellate ${ }^{*}$ & & & & & & & & & & $\mathrm{x}$ & & \\
\hline Gymnodinium sp. GSSW10* & & & & & & & & & & $\mathrm{x}$ & & \\
\hline Warnowia sp. BSL-2009a* ${ }^{*}$ & & & & & & & & & & & & $\mathrm{x}$ \\
\hline Biecheleria natalensis* & & & & & & & & $\mathrm{x}$ & & $\mathrm{x}$ & & \\
\hline Biecheleria uncultured dinoflagellate* & & & & & & & $\mathrm{x}$ & & & $\mathrm{x}$ & $\mathrm{x}$ & $\mathrm{x}$ \\
\hline Symbiodinium uncultured dinoflagellate & & & & $\mathrm{x}$ & & & & $\mathrm{x}$ & $\mathrm{x}$ & & & $\mathrm{x}$ \\
\hline Pelagodinium beii & $\mathrm{x}$ & $\mathrm{x}$ & $\mathrm{x}$ & & & & $\mathrm{x}$ & $\mathrm{x}$ & $\mathrm{x}$ & & $\mathrm{x}$ & $\mathrm{x}$ \\
\hline Pelagodinium uncultured marine dinoflagellate & & & $\mathrm{x}$ & & $\mathrm{x}$ & & $\mathrm{x}$ & $\mathrm{x}$ & & & & \\
\hline Suessiaceae uncultured eukaryote & & $\mathrm{x}$ & & & & & & & & & $\mathrm{x}$ & \\
\hline Gonyaulax cochlea & & & & $\mathrm{x}$ & $\mathrm{x}$ & $\mathrm{x}$ & & $\mathrm{x}$ & $\mathrm{x}$ & & $\mathrm{x}$ & $\mathrm{x}$ \\
\hline Gonyaulax spinifera & $\mathrm{x}$ & $\mathrm{x}$ & & & & & & $\mathrm{x}$ & & & $\mathrm{x}$ & \\
\hline Heterocapsa niei & & $\mathrm{x}$ & & $\mathrm{x}$ & $\mathrm{x}$ & & & $\mathrm{x}$ & & $\mathrm{x}$ & & $\mathrm{x}$ \\
\hline Heterocapsa uncultured dinoflagellate & & & & $\mathrm{x}$ & & & & & & & $\mathrm{x}$ & \\
\hline Alexandrium uncultured eukaryote & & $\mathrm{x}$ & & & & & & & & & & \\
\hline Azadinium sp. uncultured eukaryote* & & & & & & & & & & & $\mathrm{x}$ & \\
\hline Lessardia uncultured marine eukaryoteq & & & & $\mathrm{x}$ & & & & & & & & \\
\hline Scrippsiella uncultured eukaryote & & $\mathrm{x}$ & & & & & & & & & & \\
\hline Sinophysis uncultured marine eukaryote & & & & & & $\mathrm{x}$ & & $\mathrm{x}$ & & & & \\
\hline Dinophyceae uncultured eukaryote & & & $\mathrm{x}$ & & $\mathrm{x}$ & & $\mathrm{x}$ & $\mathrm{x}$ & $\mathrm{x}$ & & & $\mathrm{x}$ \\
\hline Dinophyceae uncultured; uncultured eukaryote* & & & & & & & & & $\mathrm{x}$ & & & \\
\hline Dinophyceae uncultured freshwater eukaryote & $\mathrm{x}$ & & & & & & $\mathrm{x}$ & & & & & $\mathrm{x}$ \\
\hline Haplozoon uncultured eukaryote ${ }^{*}$ & & & & & & & $\mathrm{x}$ & & & & & \\
\hline Noctilucales uncultured eukaryote & & $\mathrm{x}$ & & $\mathrm{x}$ & $\mathrm{x}$ & $\mathrm{x}$ & $\mathrm{x}$ & $\mathrm{x}$ & & $\mathrm{x}$ & $\mathrm{x}$ & $\mathrm{x}$ \\
\hline \multicolumn{13}{|l|}{ Protalveolata } \\
\hline Chromera uncultured freshwater eukaryote & & $\mathrm{x}$ & & & & & $\mathrm{x}$ & $\mathrm{x}$ & & & & \\
\hline \multicolumn{13}{|l|}{ Ochrophyta } \\
\hline Bolidomonas uncultured marine eukaryote* & & & & & & & & & $\mathrm{x}$ & & & \\
\hline Apedinella radians & & $\mathrm{x}$ & & & & & & & & & & \\
\hline Ciliophrys infusionum* ${ }^{*}$ & & & & & & & & $\mathrm{x}$ & & & & \\
\hline Pedinellales uncultured marine eukaryote & $\mathrm{x}$ & & & & & & $\mathrm{x}$ & & & & & \\
\hline Pedinellales uncultured marine picoeukaryote & $\mathrm{x}$ & & & & & & $\mathrm{x}$ & & & & & \\
\hline Eustigmatales uncultured stramenopile & & $\mathrm{x}$ & $\mathrm{x}$ & & & & $\mathrm{x}$ & & & & & \\
\hline Eustigmatales uncultured eukaryote & & $\mathrm{x}$ & & & & & & & $\mathrm{x}$ & $\mathrm{x}$ & & \\
\hline Aureococcus anophagefferens & & & & & & & & & & $\mathrm{x}$ & & \\
\hline Chattonellales MOCH-3q & & & & & $\mathrm{x}$ & & & & & & & \\
\hline Chattonellales uncultured eukaryoteq & & $\mathrm{x}$ & & $\mathrm{x}$ & & $\mathrm{x}$ & & & & & & \\
\hline Chloromorum sp. toxicum & & & & & & $\mathrm{x}$ & & & & & & \\
\hline
\end{tabular}



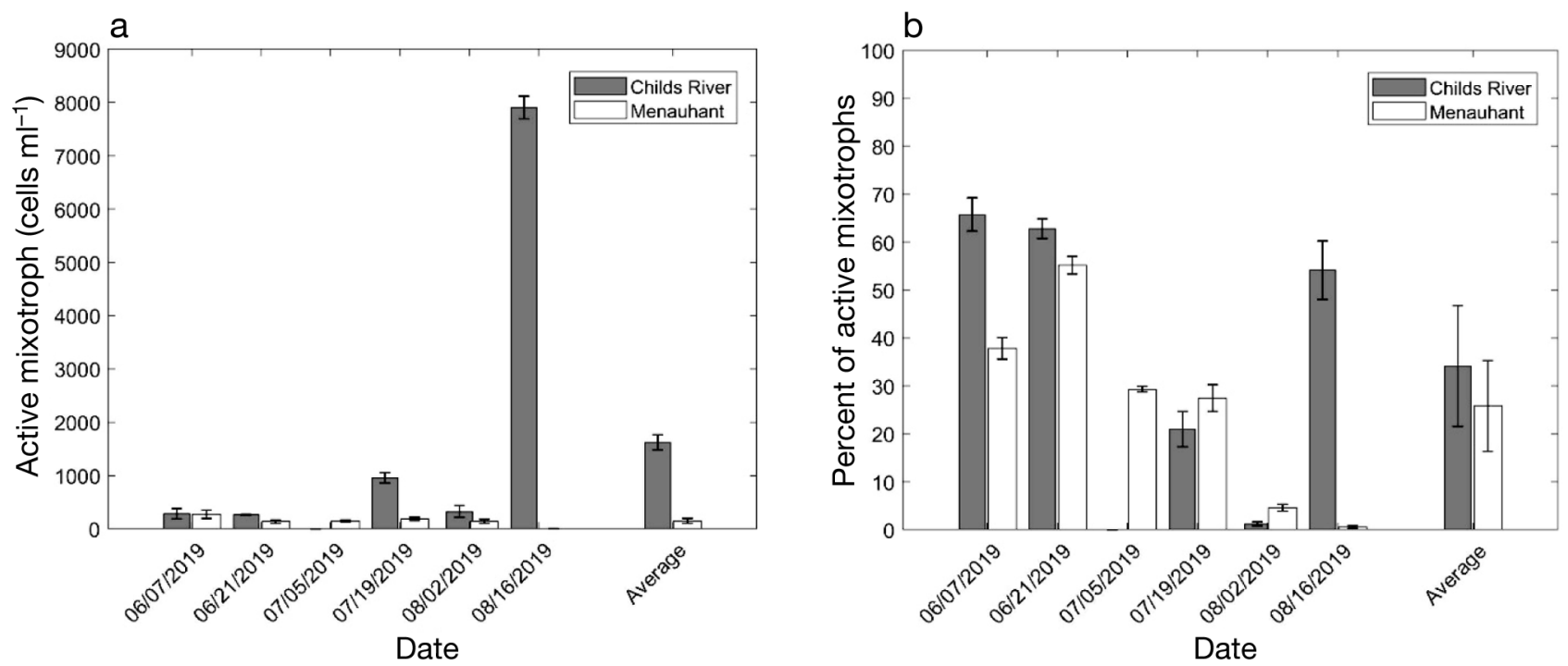

Fig. 4. Estimated (a) abundance and (b) percentage of active mixotrophs in microscopy samples collected between June and August 2019 based on the genera of chloroplast-containing plankton that were identified to be ingesting bacteria for the bromodeoxyuridine experiment for each week. Dates (mo/d/yr) correspond to collection dates. Error bars are SE
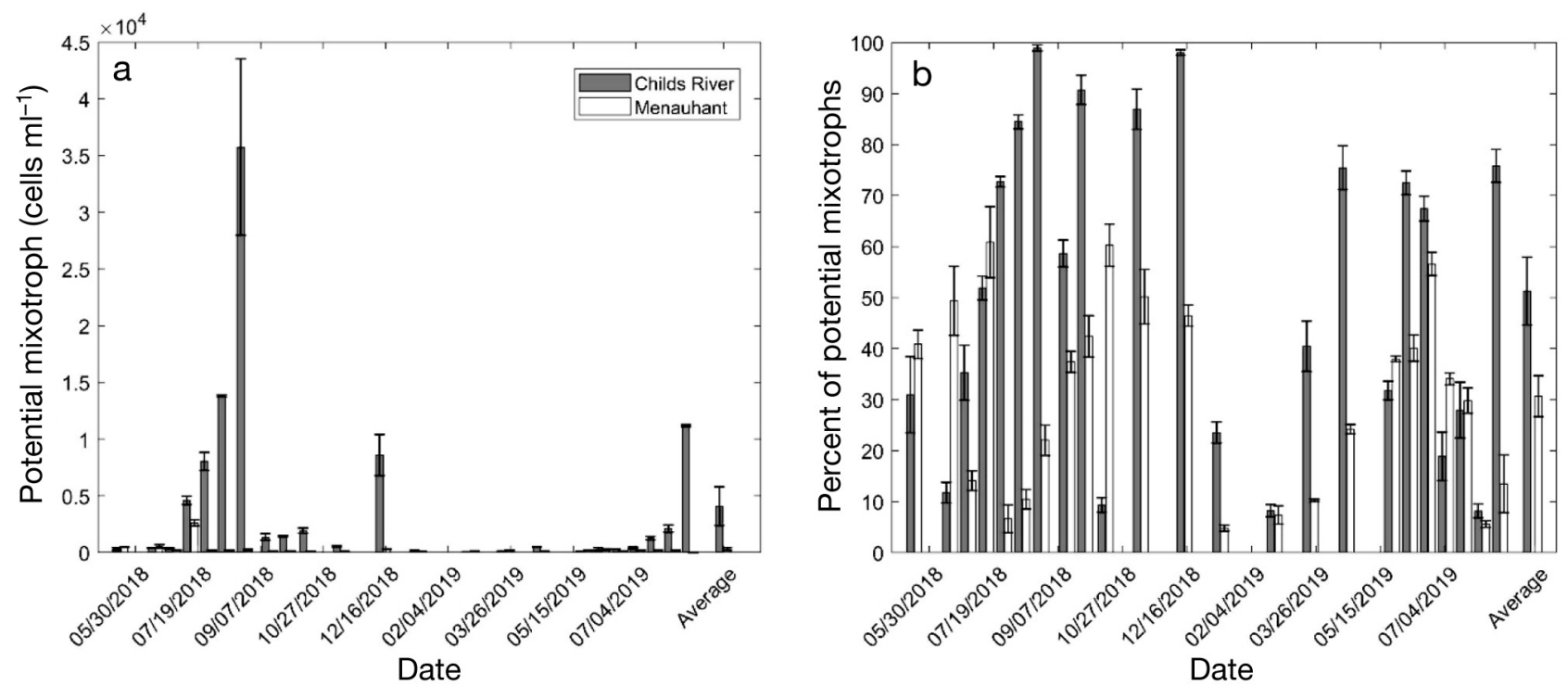

Fig. 5. Estimated (a) abundance and (b) percentage of potential mixotrophs in all microscopy samples based on the genera of chloroplast-containing plankton that were identified to be ingesting bacteria by the bromodeoxyuridine experiments run between June 2019 and August 2019. Dates are mo/d/yr. Error bars are SE

not make sense, likely because of the high variability in this factor. Increased sampling frequency could help improve our statistical strength and elucidate the real significance of stratification on temporal variability at $\mathrm{CR}$.

Regarding mixotrophy, our approach of combining BrdU experimental data with microscopy results made it possible to estimate that potential mixotrophs accounted for, on average, one-third to onehalf of the $>10 \mu \mathrm{m}$ phototrophic assemblages and that the spatial difference in those estimations was largely related to the proportion of diatoms and dino- flagellates at each site. Diatoms are the only protistan phytoplankton group with no known mixotrophic species (Flynn et al. 2013). Therefore, the proportion of potential mixotrophs $>10 \mu \mathrm{m}$ is expected to be lower at $\mathrm{MH}$ compared to $\mathrm{CR}$ since the average proportion of diatoms was significantly higher at $\mathrm{MH}$ (Table 2). Many of the potential mixotrophs identified belonged to taxa in the cryptophyte and dinoflagellate groups. The most prominent group was cryptophytes, but the average proportion of cryptophytes was not significantly different between the 2 stations. This means that while cryptophytes account 

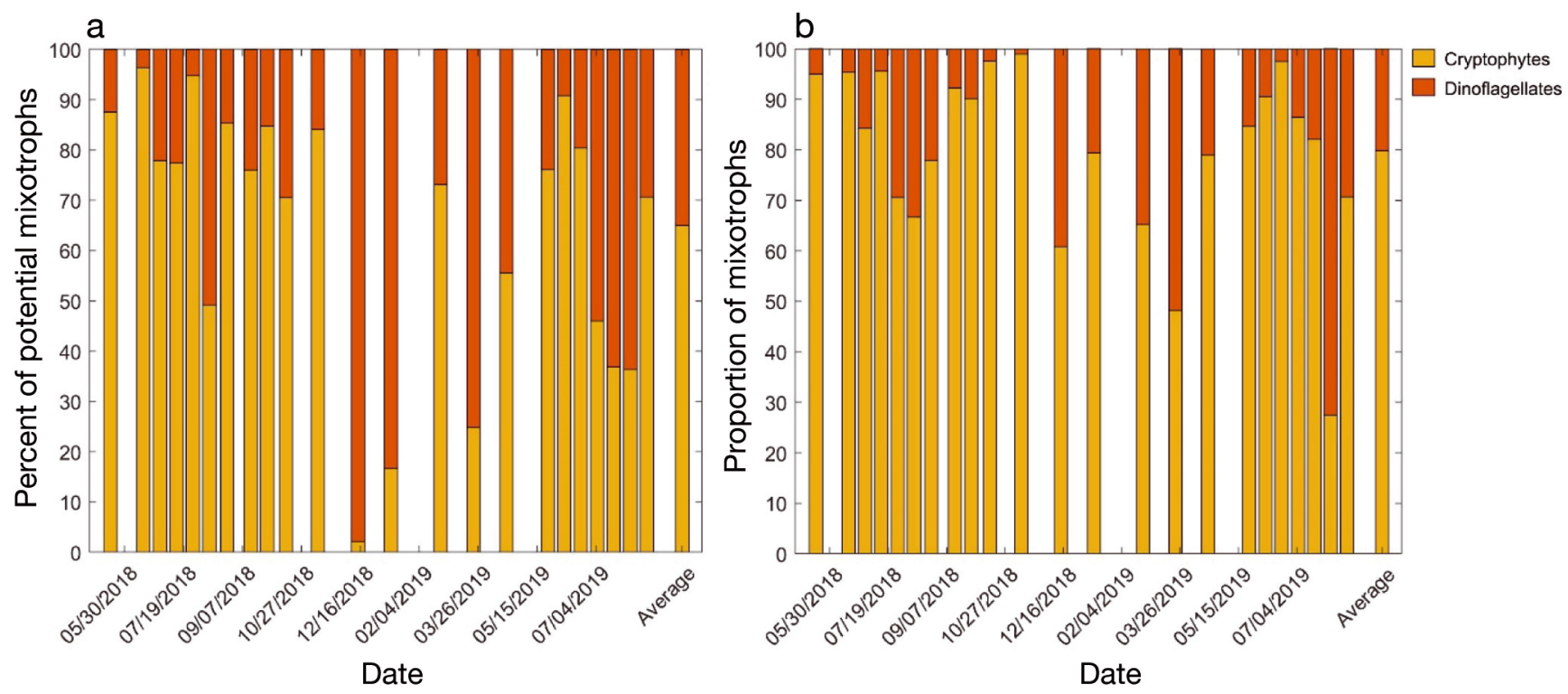

Fig. 6. Proportion of estimated potential mixotrophs composed of cryptophytes and dinoflagellates at (a) Childs River and (b) Menauhant. Average data point is the average proportion of each group over the course of the study

for the largest proportion of mixotrophs at both stations (Fig. 6), the difference in the proportion of mixotrophs between stations was not driven by cryptophytes. Instead, the microscopy-estimated proportion of mixotrophs was higher at CR compared to $\mathrm{MH}$ due to a combination of a lower proportion of diatoms and a higher proportion of dinoflagellates at CR (Table 2). However, looking at just the diatom:dinoflagellate ratio in a sample from any system will not provide complete insight into when and where mixotrophs dominate; all taxa should be considered.

The temporal variability of potential mixotroph abundance and proportion was high at both stations (Fig. 5). It has long been hypothesized that mixotrophs dominate the plankton community when either light or nutrients are limiting (Stoecker 1998, Edwards 2019). This appears to describe both CR, a station with sufficient inorganic nitrogen concentration and potentially reduced irradiance levels, and $\mathrm{MH}$, a station with lower nitrogen concentration and potentially sufficient irradiance level (Table 1). Subregions of an estuary with significant freshwater inflow, such as at $\mathrm{CR}$, are associated with high turbidity, sediment and detritus input, and resuspension, all of which reduce irradiance (Kemp et al. 2005). The GLM analysis suggested that potential mixotroph abundance was related to higher turbidity, which would support a light limitation hypothesis. Assuming light was the growth-limiting factor at CR, collection of data on irradiance levels, not just turbidity, might provide more insight into when mixotrophs dominate the photosynthetic community. At $\mathrm{MH}$, po- tential mixotroph abundance was related to higher temperatures and lower $\mathrm{NO}_{\mathrm{x}}$ concentrations, i.e. summer conditions. Considering that turbidity was lower at $\mathrm{MH}$ compared to $\mathrm{CR}$, albeit not significantly (Table 1), nutrient limitation potentially played a larger role than light limitation.

Recent analysis in the southern North Sea suggested that there was little evidence of mixotrophs in turbid eutrophic temperate estuaries (Schneider et al. 2020), similar to conditions in Waquoit Bay. However, our analysis demonstrates that it is possible for mixotrophs to account for a high proportion of the photosynthetic assemblage. Our results do not contradict Schneider et al. (2020), or vice versa, because estuaries are highly heterogeneous, and it can be difficult to directly compare 2 systems. This indicates that more research on mixotrophs across estuaries could help to identify the type that favors mixotrophs and when they are an important part of the food web. For example, Chesapeake Bay is a well-studied estuarine system with robust data on the phototrophic assemblage but lacks data on the abundance and proportion of mixotrophs. Given the well-documented presence of dinoflagellates throughout the year (Mulholland et al. 2018), it would be expected that Chesapeake Bay would favor mixotrophs under appropriate conditions. However, research is needed to identify these conditions.

Our estimation of potential mixotrophs in the microscopy samples has drawbacks, but we believe it is useful in highlighting how much of the photosynthetic assemblage in temperate estuaries can be 
mixotrophs even if they are not actively engaged in their alternative nutrient acquisition mode. It is possible that we were simultaneously under- and overestimating the abundance of different mixotrophs. We were unable to microscopically identify most of the mixotrophic ASVs, potentially underestimating our total number of potential mixotrophs. As previously mentioned, the ASVs that were not identified in microscopic samples consisted of taxa that were too small $(10-15 \mu \mathrm{m})$ to be identified (such as Ostreococcus spp. and Microglena sp.) and certain dinoflagellate species. This incongruence between microscopy and amplicon data has been noted in many recent studies that have compared the 2 approaches (e.g. Eiler et al. 2013, Gong et al. 2020, Rynearson et al. 2020). The abundances of the small genera were not included in our total abundance of phototrophs; therefore, the identification of potential mixotrophs was biased towards larger species, which tended to be dinoflagellates. This bias may have affected our interpretation regarding the difference in mixotroph proportion between stations, which we related to the balance between diatoms versus dinoflagellates.

If we were able to identify and count smaller taxa such as Ostreococcus and Microglena, then our estimation of both potential mixotroph abundance and total photosynthetic cell abundance would likely increase. Even with this increase in the proportion of potential mixotroph abundance, large mixotrophs would still likely dominate the total biomass of mixotrophs because dinoflagellates are known for their high carbon content compared to other taxa groups (Menden-Deuer \& Lessard 2000). If the proportion of potential mixotrophs was altered by including smaller species, then our understanding of factors influencing spatial and temporal variability might be different. This bias is an issue not only in our analysis but in any study that uses taxonomybased identification of mixotrophs in microscopy samples. However, our analysis (and previous analysis) is not rendered invalid by this caveat but is merely restricted to larger mixotrophs $(>10 \mu \mathrm{m})$. It should also be noted that many of these smaller species were not previously reported as mixotrophs, and further laboratory work would help clarify this status.

In the case of larger dinoflagellate-associated ASVs, their lack of identification in microscopy samples was likely the result of misidentification or abundances being too low to be detected. While misidentification is possible, it is most likely to occur with athecate genera, such as Gymnodinium sp. and Gyrodinium sp., because of their less-defined morphologies compared to thecate dinoflagellates. In this case, Gymno- dinium sp. and Gyrodinium sp. were both mixotrophs, so the abundance of potential mixotrophs would not change, but it is possible that this would result in an overestimate if heterotrophic and phototrophic species are included in the genus (e.g. Gyrodinium). If the abundance of a species was too low to be counted in the microscopy samples, then their abundance would be too low to have an impact on the proportion of mixotrophs in a sample.

The largest source of overestimation likely came from a lack of data on which genera were actively grazing in all samples, hence the use of the term potential mixotroph. It was clear from the summer 2019 comparison of microscopy data and BrdU experiments that not every ASV was always grazing on bacteria (Table 6 ). There was 1 experiment ( $\mathrm{CR}_{\text {; July }}$ 5,2019 ) in which none of the mixotrophic ASVs associated with genera in the microscopy samples were grazing (Fig. 4). Additionally, the ASV data for Microglena uva-maris revealed an interesting pattern of mixotrophic activity; at times of high ASV abundance in the -BrdU samples at CR on June 21 and July 5, it was not identified as an active mixotroph, but it was definitively identified as mixotrophic when at lower ASV abundances. This suggests that under bloom conditions, it may grow primarily as a phototroph, but when conditions are less favorable, it ingests prey. Regardless of whether a mixotroph was actively grazing when a sample was collected, knowledge of when a phototrophic community is dominated by those with the ability to switch nutrient modes is worthwhile. There is an energetic cost associated with being a mixotroph, as they must simultaneously maintain chloroplasts and feeding vacuoles (Stoecker 1998). Even if a mixotroph is not engaged in its alternative nutrient acquisition mode, it should dominate under different conditions than a pure phytoplankter. Therefore, studying potential mixotrophs still provides important information about the type of organisms in the phototrophic community.

From our analysis, it is clear that even with the limited match of 7 ASVs with 6 genera by microscopy, mixotrophic species can be an important part of the phototrophic community in temperate estuaries, at times accounting for up to $98 \%$ of the group. Very little is known about the presences of mixotrophs in estuarine systems across different temporal scales (diurnal, tidal, seasonal, annual, etc.). Using taxonomy to estimate the potential abundance of mixotrophs in plankton samples, as demonstrated here and in Schneider et al. (2020), can help to begin expanding our knowledge of this trophic mode in estu- 
aries. Estimates of potential mixotroph abundance by using plankton taxonomy could be readily accomplished in systems with robust plankton assemblage data, such as Chesapeake Bay. However, our work also demonstrates that estimating the abundance of mixotrophs through taxonomy is imperfect due to 2 primary challenges: not all phagotrophic phototroph taxa are known, and the conditions under which they actively graze are often unclear. We suggest that using BrdU incubations can provide a constraint on estimations of mixotroph abundance by only detecting taxa actively grazing in a given sample. We acknowledge that it is a costly and time-consuming method, but widespread estimations of mixotroph abundance based on taxonomy of plankton samples, supplemented with BrdU incubations, when possible, would rapidly increase our understanding of mixotrophic components.

Acknowledgements. The authors thank WBNERR and the Waquoit BayWatchers for sharing their water quality data and all the volunteers who assisted in counting and identifying the phytoplankton samples. We also thank Dr. Grace Chiu and the VIMS Environmental Statistics and Transdisciplinary Data Science (ESTDatS) Laboratory for their assistance with the statistical analysis. We acknowledge Dr. Jean-David Grattepanche's significant contribution to revision of the BrdU immunoprecipitation protocol. N.C.M. was funded by a Woods Hole Sea Grant Postdoctoral Fellowship (award number NA14OAR4170074), and M.dC. was funded by a WHOI Summer Student Fellowship. This is VIMS contribution number 4057 .

\section{LITERATURE CITED}

Anderson R, Jürgens K, Hansen PJ (2017) Mixotrophic phytoflagellate bacterivory field measurements strongly biased by standard approaches: a case study. Front Microbiol 8:1398

Brierley AS (2017) Plankton. Curr Biol 27:R478-R483

Buchanan C (2020) A water quality binning method to infer phytoplankton community structure and function. Estuaries Coasts 43:661-679

Cesar-Ribeiro C, Piedras FR, da Cunha LC, da Lima DT, Pinho LQ, Moser GAO (2020) Is oligotrophy an equalizing factor driving microplankton species functional diversity within Agulhas rings? Front Mar Sci 7:599185

Clarke KR, Gorley RN (2015) Primer v7: user manual/tutorial. PRIMER-e, Plymouth

* Cohen RRH (1985) Physical processes and the ecology of a winter dinoflagellate bloom of Katodinium rotundatum. Mar Ecol Prog Ser 26:135-144

* Cullen JJ (1982) The deep chlorophyll maximum: comparing vertical profiles of chlorophyll $a$. Can J Fish Aquat Sci 39:791-803

* D'Avanzo C, Kremer JN (1994) Diel oxygen dynamics and anoxic events in an eutrophic estuary of Waquoit Bay, Massachusetts. Estuaries 17:131-139

Edwards KF (2019) Mixotrophy in nanoflagellates across environmental gradients in the ocean. Proc Natl Acad Sci
USA 116:6211-6220

* Eiler A, Drakare S, Bertilsson S, Pernthaler J and others (2013) Unveiling distribution patterns of freshwater phytoplankton by a next generation sequencing based approach. PLOS ONE 8

Fay SA, Gast RJ, Sanders RW (2013) Linking bacterivory and phyletic diversity of protists with a marker gene survey and experimental feeding with BrdU-labeled bacteria. Aquat Microb Ecol 71:141-153

Flynn KJ, Stoecker DK, Mitra A, Raven JA and others (2013) Misuse of the phytoplankton-zooplankton dichotomy: the need to assign organisms as mixotrophs within plankton functional types. J Plankton Res 35:3-11

Foster SQ, Fulweiler RW (2019) Estuarine sediments exhibit dynamic and variable biogeochemical responses to hypoxia. J Geophys Res Biogeosci 124:737-758

Fox J, Weisberg S (2016). Companion to applied regression. R package version 2.1-3. https://cran.r-project.org/ package $=$ car

Gast RJ, Dennett MR, Caron DA (2004) Characterization of protistan assemblages in the Ross Sea, Antarctica, by denaturing gradient gel electrophoresis. Appl Environ Microbiol 70:2028-2037

Gast RJ, Fay SA, Sanders RW (2018) Mixotrophic activity and diversity of Antarctic marine protists in austral summer. Front Mar Sci 5:13

Glibert PM, Wilkerson FP, Dugdale RC, Raven JA and others (2016) Pluses and minuses of ammonium and nitrate uptake and assimilation by phytoplankton and implications for productivity and community composition, with emphasis on nitrogen-enriched conditions. Limnol Oceanogr 61:165-197

KGong W, Hall N, Paerl H, Marchetti A (2020) Phytoplankton composition in a eutrophic estuary: comparison of multiple taxonomic approaches and influence of environmental factors. Environ Microbiol 22:4718-4731

* Halbach L, Vihtakari M, Duarte P, Evertt A and others (2019) Tidewater glaciers and bedrock characteristics control the phytoplankton growth environment in a fjord in the Arctic. Front Mar Sci 6:254

* Haraguchi L, Jakobsen HH, Lundholm N, Carstensen J (2018) Phytoplankton community dynamic: a driver for ciliate trophic strategies. Front Mar Sci 5:272

Howes B, Samimy R, Schlezinger D, Eichner E, Kelley S, Ramsey J, Detjens P (2013) Linked watershed-embayment approach to determine critical nitrogen loading thresholds for the Waquoit Bay and Eel Pond embayment system, towns of Falmouth and Mashpee, Massachusetts. Massachusetts Department of Environmental Protection, Boston, MA. www.mashpeema.gov/sites/g/files/ vyhlif3426/f/uploads/mepwaquoituc.pdf

*Hugerth LW, Muller EEL, Hu DYOO, Lebrun LAM (2014) Systematic design of 18S rRNA gene primers for determining eukaryotic diversity in microbial consortia. PLOS ONE 9:e95567

Jauzein C, Couet D, Blasco T, Lemée R (2017) Uptake of dissolved inorganic and organic nitrogen by the benthic toxic dinoflagellate Ostreopsis cf. ovata. Harmful Algae 65:9-18

* Kemp WM, Boynton WR, Adolf JE, Boesch DF and others (2005) Eutrophication of Chesapeake Bay: historical trends and ecological interactions. Mar Ecol Prog Ser 303:1-29

* Leles SG, Mitra A, Flynn KJ, Tillman U and others (2019) Sampling bias misrepresents the biogeographical signif- 
icance of constitutive mixotrophs across global oceans. Glob Ecol Biogeogr 28:418-428

Li J, Glibert PM, Zhou M (2010) Temporal and spatial variability in nitrogen uptake kinetics during harmful dinoflagellate blooms in the East China Sea. Harmful Algae 9:531-539

Li Q, Edwards KF, Schvarcz CR, Selph KE, Steward GF (2021) Plasticity in the grazing ecophysiology of Florenciella (Dichtyochophyceae), a mixotrophic nanoflagellate that consumes Prochlorococcus and other bacteria. Limnol Oceanogr 66:47-60

Lomas MW, Bonachela JA, Levin SA, Martiny AC (2014) Impact of ocean phytoplankton diversity on phosphate uptake. Proc Natl Acad Sci USA 111:17540-17545

Margalef R (1978) Life-forms of phytoplankton as survival alternatives in an unstable environment. Oceanol Acta 1:493-509

Marshall HG, Burchardt L, Lacouture R (2005) A review of phytoplankton composition within Chesapeake Bay and its tidal estuaries. J Plankton Res 27:1083-1102

Menden-Deuer S, Lessard EJ (2000) Carbon to volume relationships for dinoflagellates, diatoms, and other protist plankton. Limnol Oceanogr 45:569-579

Millette NC, Grosse J, Johnson WM, Jungbluth MJ, Suter EA (2018) Hidden in plain sight: the importance of cryptic interactions in marine plankton. Limnol Oceanogr Lett 3:341-356

Mitra A, Flynn KJ, Tillmann U, Raven JA and others (2016) Defining planktonic protist functional groups on mechanisms for energy and nutrient acquisition: incorporation of diverse mixotrophic strategies. Protist 167:106-120

Mulholland MR, Morse R, Egerton T, Bernhardt PW, Filippino KC (2018) Blooms of dinoflagellate mixotrophs in a lower chesapeake bay tributary: carbon and nitrogen uptake over diurnal, seasonal, and interannual timescales. Estuar Coast 41:1744-1765

Ptacnik R, Solimini AG, Andersen T, Tamminen T and others (2008) Diversity predicts stability and resource use efficiency in natural phytoplankton communities. Proc Natl Acad Sci USA 105:5134-5138

Rynearson TA, Flickinger SA, Fontaine DN (2020) Metabarcoding reveals temporal patterns of community composition and realized thermal niches of Thalassiosira spp. (Bacillariophyceae) from the Narragansett Bay long-term plankton time series. Biology (Basel) 9:19

Schneider LK, Flynn KJ, Herman PMJ, Troost TA, Stolte W (2020) Exploring the trophic spectrum: placing mixoplankton into marine protist communities of the southern North Sea. Front Mar Sci 7:586915

Shashi Shekhar TR, Kiran BR, Puttaiah ET, Shivaraj Y, Mahadevan KM (2008) Phytoplankton as index of water quality with reference to industrial pollution. J Environ Biol 29:233-236

Sherr EB, Sherr BF (1993) Preservation and storage of samples for enumeration of heterotrophic protists. In: Kemp

Editorial responsibility: Steven Lohrenz

New Bedford, Massachusetts, USA

Reviewed by: 3 anonymous referees
PF, Sherr BF, Sherr EB, Cole JJ (eds) Handbook of methods in aquatic microbial ecology. Lewis Publishers, Boca Raton, FL, p 207-212

* Smayda TJ, Reynolds CS (2001) Community assembly in marine phytoplankton: application of recent models to harmful dinoflagellate blooms. J Plankton Res 23: $447-461$

Steele JH (1962) Environmental control of photosynthesis in the sea. Limnol Oceanogr 7:137-150

Stoeck T, Bass D, Nebel M, Christen R, Jones MDM, Breiner HW, Richards TA (2010) Multiple marker parallel tag environmental DNA sequencing reveals a highly complex eukaryotic community in marine anoxic water. Mol Ecol 19:21-31

* Stoecker DK (1998) Conceptual models of mixotrophy in planktonic protists and some ecological and evolutionary implications. Eur J Protistol 34:281-290

Strickland JDH (1965) Production of organic matter in the primary stages of the marine food web chain. In: Riley JP, Skirrow G (eds) Chemical oceanography, Vol 1. Academic Press, New York, NY, p 477-610

* Tian W, Zhang H, Zhao L, Zhang F, Huang H (2017) Phytoplankton diversity effects on community biomass and stability along nutrient gradients in a eutrophic lake. Int J Environ Res Public Health 14:95-109

Tomasky-Holmes G, Valiela I, Charette MA (2013) Determination of water mass ages using radium isotopes as tracers: implications for phytoplankton dynamics in estuaries. Mar Chem 156:18-26

* Tragin M, Zingone A, Vaulot D (2018) Comparison of coastal phytoplankton composition estimated from the V4 and V9 regions of the 18S rRNA gene with a focus on photosynthetic groups and especially Chlorophyta. Environ Microbiol 20:506-520

US EPA (2006) Volunteer estuary monitoring: a methods manual. EPA:842-B-06-003, EPA Office of Water, Washington, DC

*Valiela I, Foreman K, LaMontagne M, Hersh D and others (1992) Couplings of watersheds and coastal waters: sources and consequences of nutrient enrichment in Waquoit Bay, Massachusetts. Estuaries 15:443-457

V Valiela I, Owens C, Elmstrom E, Lloret J (2016) Eutrophication of Cape Cod estuaries: effect of decadal changes in global-driven atmospheric and local-scale wastewater nutrient loads. Mar Pollut Bull 110:309-315

*Vallina SM, Follows MJ, Dutkiewicz S, Montoya JM, Cermeno P, Loreau M (2014) Global relationship between phytoplankton diversity and productivity in the ocean. Nat Commun 5:4299

* Ward BA, Follows MJ (2016) Marine mixotrophy increases trophic transfer efficiency, mean organism size, and vertical carbon flux. Proc Natl Acad Sci USA 113:2958-2963

* Zuur AF, Ieno EN, Elphick CS (2010) A protocol for data exploration to avoid common statistical problems. Methods Ecol Evol 1:3-14

Submitted: January 29, 2021

Accepted: August 2, 2021

Proofs received from author(s): October 21, 2021 